\title{
Cardiac Enhancer Activity of the Homeobox Gene tinman Depends on CREB Consensus Binding Sites in Drosophila
}

\author{
Tyamagondlu V. Venkatesh, Maiyon Park, Karen Ocorr, Jill Nemaceck, Krista Golden, \\ Matthew Wemple, and Rolf Bodmer* \\ Department of Biology, University of Michigan, Ann Arbor, Michigan \\ Received 21 September 1999; Accepted 13 October 1999
}

\begin{abstract}
Summary: The Drosophila homeobox gene tinman plays a critical role in subdividing the early mesoderm. In particular, tinman is absolutely required for formation of the heart and visceral mesoderm. tinman expression is initiated throughout the mesoderm of the trunk region under the control of the bHLH transcription factor encoded by the twist gene, a determinant of all mesoderm. Later, tinman expression is restricted to the dorsal portion of the mesoderm, a process that is directed by decapentaplegic ( $d p p)$ whose product (a TGF- $\beta$-related protein) is secreted by the overlaying ectoderm. Further restriction of tinman expression to the cardiac progenitors, in which it will persist throughout development, involves the secreted segmentation gene product encoded by wingless (wg, a Drosophila Wnt gene). Here, we show that strong early expression depends on the synergistic action of an enhancer element at the $5^{\prime}$ end of the gene in conjunction with an element in the first intron. Moreover, two distinct enhancer regions are responsible for tinman expression in the heart: one region confers expression in the heat tube associated pericardial cells, the other element drives expression in the contractile, myocardial cells. The latter element contains two CREB consensus binding sites that are essential for cardiacspecific expression. genesis 26:55-66, 2000. (c) 2000 Wiley-Liss, Inc.
\end{abstract}

Key words: Drosophila; tinman; mesoderm; heart; cardiogenesis; patterning; CREB

\section{INTRODUCTION}

The molecular processes involved in mesoderm determination and muscle subtype specification have been studied in some detail (for review see Abmayr et al., 1995; Baylies et al., 1998; Bodmer and Frasch, 1999). Specific gene functions have been identified that act during discrete steps of mesoderm differentiation. As a consequence, models of hierarchical networks of genetic interactions have been proposed to govern the sequential embryological events in mesoderm differentiation (for review see Bodmer and Frasch, 1999). At the top of the hierarchy is twist, which encodes a basic-helix-loop-helix protein (Thisse et al., 1988) and acts as the first zygotic determinant of mesoderm formation. At blastoderm, twist activates the early pan-mesodermal expression of a number of genes, including the homeobox gene tinman (Bodmer et al., 1990; Yin et al., 1997), the zinc finger and homeobox gene $z$ fh-1 (Lai et al., 1991), the MADS-box gene Dmef2 (Nguyen et al., 1994; Lilly et al., 1994; Cripps et al., 1998; Nguyen and $\mathrm{Xu}, 1998$ ), and FGF-receptor encoded beartless (Shishido et al., 1993). Although each of these genes plays a crucial role in mesoderm differentiation and each is first activated at a similar time point at blastoderm, their mesodermal expression patterns later in development are distinct from one another and their functions affect different processes of differentiation. For example, the FGF receptor encoded by beartless is primarily required for dorsal migration of the mesoderm (Beiman et al., 1996; Gisselbrecht et al., 1996; Shishido et al., 1997). By contrast, tinman is not required for this process of migration but rather for specifying the differentiation pathway of the dorsal portion of the mesoderm. Without tinman, most if not all derivatives of the dorsal mesoderm fail to develop, in particular the heart and visceral muscles (Bodmer, 1993; Azpiazu and Frasch, 1993). Dmef2, on the other hand, appears to function in the myogenicspecific differentiation of all muscles (Bour et al., 1995; Lilly et al., 1995; Ranganayakulu et al., 1995), rather than in the earlier specification of mesodermal subdivision or subsets of cells, as tinman and zfh-1 are (Bodmer, 1993; Azpiazu and Frasch, 1993; Lai et al., 1993; Broihier et al., 1998; Su et al., 1999).

In addition to mesoderm endogenous transcription factors, inductive mechanisms involving signals from the ectoderm are important for providing spatial information

\footnotetext{
* Correspondence to: Dr. Rolf Bodmer, Department of Biology, University of Michigan, $830 \mathrm{~N}$ University, Ann Arbor, MI 48109-1048. E-mail: rolf@umich.edu

Current address: Dr. Tyamagondlu V. Venkatesh, Monsanto-Nutrition Sector, 800 Lindbergh Blvd.-02C, St. Louis, MO 63167.

Current address: Dr. Maiyon Park, HHMI/Department of Pharmacology, K516, University of Washington, Box 357750, Seattle, WA 98195.

Contract grant sponsors: American Heart Association; National Institutes of Health, National Heart, Lung \& Blood Institute.
} 
in mesodermal subtype specification. The TGF- $\beta$ factor encoded by decapentaplegic $(d p p)$ is expressed in a broad dorsal domain of the ectoderm along the anteriorposterior axis. Dpp is secreted from the dorsal ectoderm and is necessary to maintain tinman and Dmef2 expression in the dorsal mesoderm (Staehling-Hampton et al., 1994; Frasch, 1995; Xu et al., 1998; Nguyen and Xu, 1998). In addition to the dorsal-ventral patterning role of $d p p$, the secreted segment polarity gene products encoded by wingless $(w g)$ and hedgehog ( $h b)$ are also crucial for anterior-posterior patterning of the developing mesoderm (Wu et al., 1995; Baylies et al., 1995; Lawrence et al., 1995; Azpiazu et al., 1996; Ranganayakulu et al., 1996; Park et al., 1996; Riechmann et al., 1997; for review see Bodmer and Frasch, 1999). Whereas $d p p$ and tinman are essential for both heart and visceral mesoderm formation, $w g$ is needed primarily for the cardiac component (Wu et al., 1995). Although the intersection of $w g$ and $d p p$ signaling in the context of dorsal mesodermal tinman expression appears to be instructive for cardiac cell type specification (W.K. Lockwood and R. Bodmer, unpublished data), other combinations of inductive signals and mesodermal context factors are likely to be involved in specifying other mesodermal subset of cells or contribute to further distinctions between individual cell types (see for example, Su et al., 1999).

Here, we show that the dynamic pattern of tinman expression in the mesoderm is regulated by a modular set of cis-regulatory elements. High levels of the early pan-mesodermal expression of tinman depends on the synergistic interaction between a 350 bp element $5^{\prime}$ to the coding region (Lee et al., 1997) and an element in the first intron (Yin et al., 1997). tinman expression in the heart precursors seems to be regulated by two separate elements in the $3^{\prime}$ region of the gene: One element directs expression to the pericardial cells (as well as in a subset of visceral circular muscles); the other element directs expression primarily in the myocardial cells of the heart. The myocardial-specific expression depends on two CREB consensus binding sites. We discuss the possible function of these sites as potential Dpp response elements.

\section{RESULTS}

\section{Cis-Regulatory Elements Reflect Endogenous tinman Expression}

Endogenous Tinman protein expression in the mesoderm is detected in four progressively restricted phases (Fig. 1B-E): first it is present in all the trunk mesoderm at gastrulation and during germ band extension (stage $8 / 9$ ), at stage 10 it is restricted to the dorsal mesoderm, at stage $11 / 12$ it is further restricted to the cardiac mesoderm and a subset of visceral mesoderm, and finally after stage 14 is confined to the developing heart (see also Yin et al., 1997).

In order to study the regulation of tinman expression, we generated transgenic flies with various genomic frag- ments of the tinman gene fused to the lacZ reporter gene (Fig. 1A). A large BamHI fragment (2A) that extends from about $-7 \mathrm{~kb}$ into the first intron shows expression throughout the early mesoderm (Fig. 1F). A fragment $3^{\prime}$ to $2 \mathrm{~A}$ which contains the second intron (42), the third exon and some $3^{\prime}$ untranslated ( $3^{\prime}$ UTR) and noncoding regions (34) shows expression in the pericardial cells of the heart and a subset of visceral mesoderm (Fig. 1H; see also Fig. 3). A 1.4 fragment $3^{\prime}$ to 34 contains a myocardial-specific enhancer (73; Fig. 1I). The $3^{\prime}$-most fragment we examined for reporter gene expression contains (at least part of) the dorsal mesodermal enhancer (Fig. 1G; see also Xu et al., 1998). The early mesoderm and heart enhancers have been further studied (see below).

\section{Early Mesodermal Expression Depends On Two Distinct Elements}

Although the large fragment $2 \mathrm{~A}$ confers early mesodermal expression, all fragments $5^{\prime}$ to the coding region without the first intron fail to show significant lacZ expression in the mesoderm (Fig. 2A, B). Weak to moderate expression in the early mesoderm is observed when the first intron itself is examined (Fig. 2C; see also Yin et al., 1997). However, a significant increase in lacZ expression is observed when the first intron is combined with a $350 \mathrm{bp}$ element from the $5^{\prime}$ region (or a larger region containing that element) in the same construct (Fig. 2A, D, E). Interestingly, both of these elements contain a number of putative Twist binding sites (Yin et al., 1997; Lee et al., 1997). Thus, it appears that an element $5^{\prime}$ to the coding region cooperates with an intronic element to direct the early twist-dependent expression of tinman.

\section{Pericardial and Visceral Mesoderm Enhancer tinman}

We wanted to further define the pericardial and visceral mesoderm expression exhibited by fragment 34 in the $3^{\prime}$ region of the tinman gene (Fig. 1A, H). Surprisingly, the pericardial nor the visceral mesoderm expression of fragment 34 cannot be localized to a unique non-protein coding region: We tested the second intron (construct $42)$, the $3^{\prime}$ UTR and the region $3^{\prime}$ to the gene (103A500), but none of them show expression of all or part of the 34 pattern (Fig. 3A; data not shown). Only the subfragment 56 that contains protein coding sequence $3^{\prime}$ to the homeodomain shows 34-like pericardial and visceral mesoderm expression (Fig. 3B,C). Thus, it is likely that this $3^{\prime}$ protein-coding region is necessary for pericardial and visceral mesoderm expression. However, we do not yet know if this is the only element needed or if other regions within fragment 56 are also necessary. Although tinman RNA does not persist in the forming visceral mesoderm past stage 11, Tinman protein is present in a segmented pattern until stage 13 (Fig. 4D). Thus, part of Tinman's expression in the visceral mesoderm seems to be encoded by an element that is linked to or overlaps with the pericardial element. 
Myocardial Heart Cell Enhancer Maps to an Element $3^{\prime}$ of the Coding Region

Expression of fragment $73(1.4 \mathrm{~kb})$ is restricted exclusively to the myocardial cells of the forming heart and directs lac $Z$ expression from stage 12 on. As Tinman protein, lac $Z$ expression is confined to four of the six myocardial cells within each hemisegment (Fig. 1E, I). Unlike Tinman protein, however, no pericardial cell expression is detected with this construct. Thus, it seems that myocardial and pericardial expression is regulated by enhancer elements that act independently from one another.

To determine the minimal size of this myocardial heart enhancer of tinman, we examined 600 bp overlapping fragments derived from construct 73 (fragments 103A-C; Fig. 4A). Even though fragment 103A overlaps with $103 \mathrm{C}$ for only $22 \mathrm{bp}$ (300bp with 103B), transgenic embryos of all three fragments (103A-C) exhibit lacZ reporter gene expression in the myocardial cells (Fig. $4 \mathrm{~B}-\mathrm{D})$. Interestingly however, the level of expression along the anterior posterior axis varies significantly between the constructs $103 \mathrm{~A}$ to $103 \mathrm{C}$. Whereas fragment 103B mediate uniformly strong expression (as is fragment 73, Fig. 4C), fragment 103A promotes strong expression only in the anterior myocardial cells, which gradually diminishes posteriorly (Fig. 4B). Conversely, fragment 103C mediates strong expression posteriorly, which gradually lessens anteriorly (Fig. 4D).

In order to characterize the myocardial heart cell enhancer fragment further, we examined the lac $Z$ reporter pattern of two slightly out of register fragments that span the small overlap between 103A and 103C (Fig. 4A): a 305bp fragment (Henh1) and a 360bp fragment (Henh2). Two copies of Henh1 (2×) driving lacZ confers high levels of cardiac-specific expression beginning at late stage 11 (Fig. 4E-H). However, reporter gene expression is no longer restricted to the Tinman subset of myocardial heart cells that is marked by $103 \mathrm{~B}$ and 73 ; rather all myocardial and the pericardial cells are anti- $\beta$ galactosidase positive with this construct (Fig. 4E-G), including the two cells per hemisegment that do not normally express tinman. Although the expanded portion of expression within the developing heart is not as strong as the 103B pattern (Fig. 4E), this pan-cardiac expansion was never observed in embryos of any of the 103B (or 73) transformant lines (Fig. 4C or 1I). Transformants with one copy of the Henh $1(1 \times)$ construct shows a similar pattern of pan-cardiac expression as Henh1 $(2 \times)$, but exhibits weaker "ectopic" expression (data not shown). Cardiac expression seems to be somewhat dosage sensitive, these data suggest that the $305 \mathrm{bp}$ Henh1 fragment is likely to be missing negative control elements that suppress expression in pericardial and a subset of myocardial cells. Transformants of Henh2 driving lac $Z$ show a similar cardiac pattern as Henh1, but the ectopic cardiac expression (in Tinman-negative myocardial cells and in pericardial cells) is less pronounced than with Henh2 (Fig. 4A and data not shown). Thus, one of the negative elements necessary for correct myocardial expression is likely to be located in the $100 \mathrm{bp}$ region $3^{\prime}$ of the Henh1 sequence (see Fig. 4A).

\section{Myocardial Heart Enhancer Activity Depends on CREB Consensus Binding Sites}

We have identified a 600 bp myocardial heart cell enhancer (103B) 3' to the tinman coding region, and have shown that much of the regulatory information for myocardial expression must be contained within the $255 \mathrm{bp}$ overlap between Henh 1 and Henh2 region. Although the restriction of tinman expression to the cardiac mesoderm appears to be directed by the changing patterns of $w g$ and $d p p$ intersects (Wu et al., 1995; Frasch 1995; W. Lockwood and R. Bodmer, unpublished data), we did not find any consensus binding sites of known $w g$ response element within this genomic region. We did, however, identify two CRE consensus sites within the 255 bp overlap between Henh1 and 2 (Fig. 4A and Fig. 5A). A consensus binding site for CREB has previously been shown to be $d p p$ responsive sequence within a visceral mesoderm enhancer of the Ultrabithorax (Ubx) (Eresh et al., 1997; Riese et al., 1997). In order to determine if the CRE consensus sites common to Hen1 and 2 are required for cardiac-specific expression, we mutated both CRE sites in Henh1 (CRE-M) and examined lac Z expression in transgenic flies (Fig. 5A). In contrast to the wild-type form of Henh1(1x) (Fig. 5B), CRE mutated Henh1(CRE-M) abolishes all heart-specific reporter gene expression in all embryos of the four independent transformants (Fig. 5C), except in one case where very weak pericardial expression is observed at late developmental stages (after the heart tube has formed, data not shown). We conclude that one or both of the CRE consensus sequences in tinman myocardial heart cell enhancer are necessary for cardiac-specific expression.

\section{DISCUSSION}

tinman expression seems to be regulated by discrete enhancer elements that are distributed $5^{\prime}$ to, $3^{\prime}$ to and within the tinman coding region (Yin et al., 1997; Lee et al., 1997; this study). It has previously been reported that the twist-dependent tinman expression in the early mesoderm is achieved by an element within the first intron (Yin et al., 1997). In addition to confirming this result, we find that the combination of the first intron with an element $5^{\prime}$ to the tinman coding region (construct 76 ) results in higher levels of reporter gene expression are achieved than with the first intron alone (Fig. 2). This suggests that a composite enhancer element is directing high levels of tinman expression in the early mesoderm.

Later, when tinman expression is restricted to the developing heart, expression in the forming cardial and pericardial cells is apparently regulated by separate enhancer elements (Figs. 3 and 4). It is noted, however, 
A

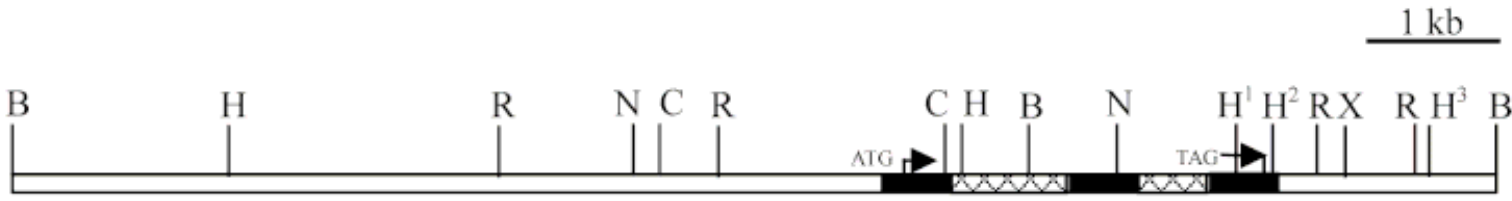

$2 \mathrm{~A} \square$ EM

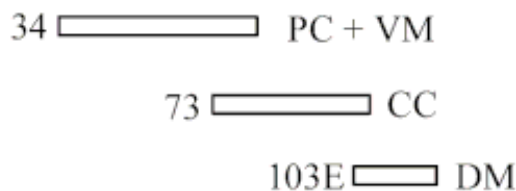

Tin

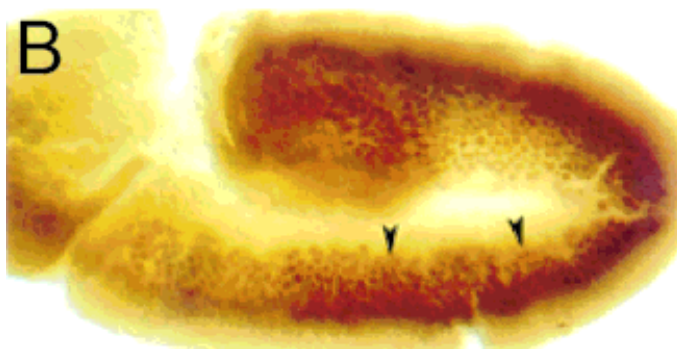

C

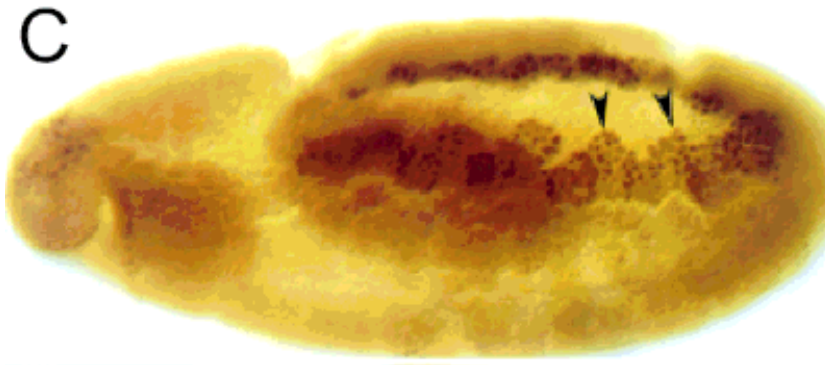

D
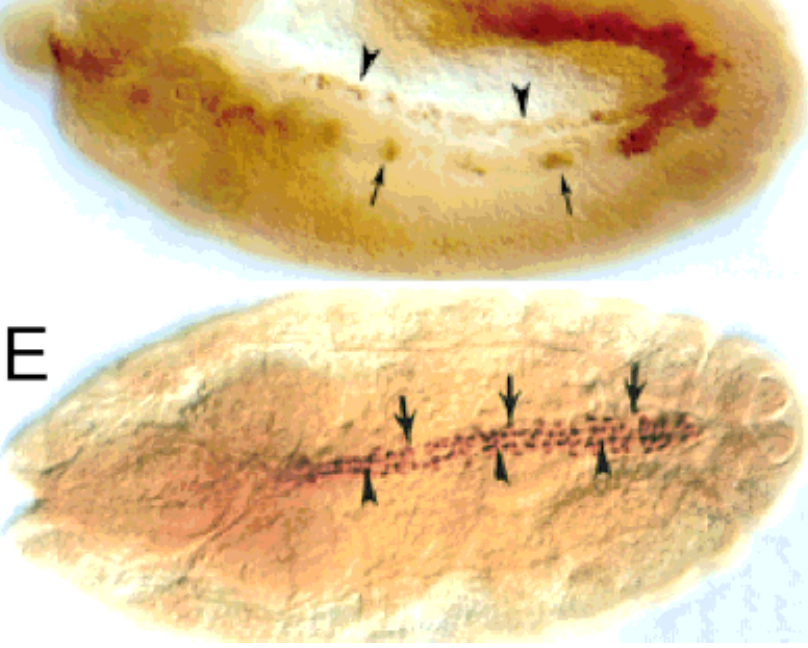

$\beta$-gal
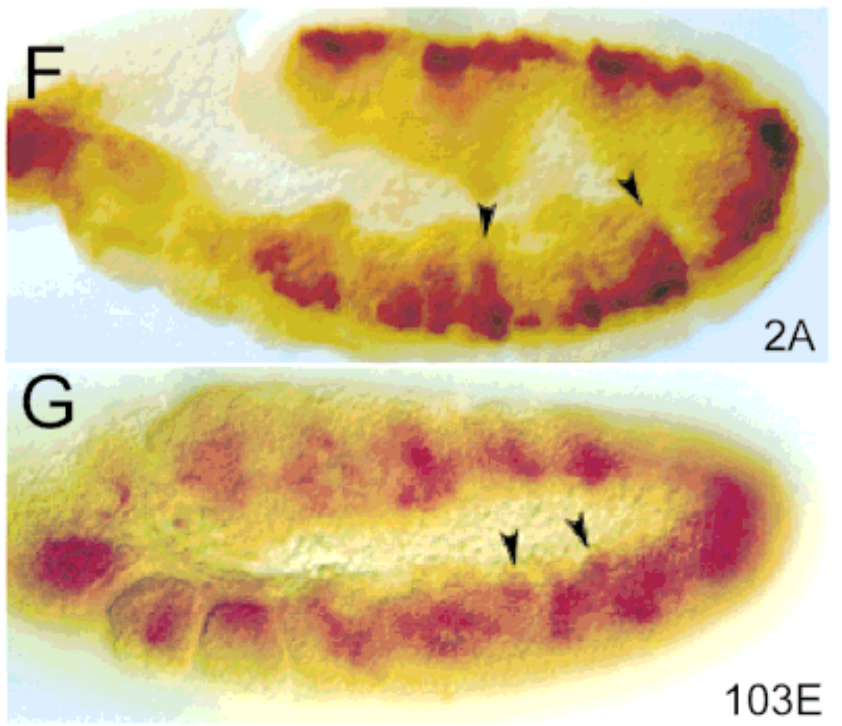

$\mathrm{H}$
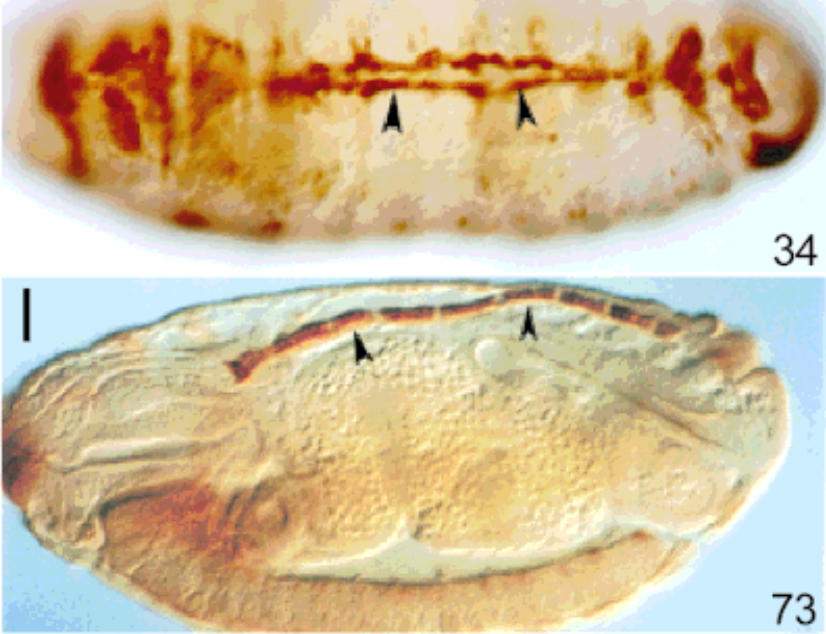

FIG 1 
that pericardial expression observed in fragment 56 transformants does not occur in blocks of four out six cells per hemisegment, as is observed for Tinman protein (Fig. 1E), but seems to be present in all pericardial cells. Pericardial expression of fragment 56 transformants is accompanied by expression in a subset of visceral mesoderm. A $5^{\prime}$ region has also been reported to confer visceral mesoderm expression (Lee et al., 1997), although we were unable to detect mesoderm-specific expression with any $5^{\prime}$ fragment by itself (Fig. 2A, B). It is thus possible that the control of unique pericardial and visceral mesoderm expression is dispersed and contributing elements are distributed among various regions of the tinman gene. Composite regulatory elements that contribute to overlapping expression patterns have been observed for other genes, for example even-skipped (Fujioka et al., 1999) and Dmef2 (Nguyen and Xu, 1998).

The $w g$ pathway appears to be specifically required for heart precursor formation and for the final confinement of tinman expression to the cardiac mesoderm (Wu et al., 1995; Park et al., 1996). However, wg responsive elements have not been identified, i.e., dTCF consensus sites (Riese et al., 1997; van de Wetering, 1997), neither in the pericardial nor the myocardial elements. Thus, the $w g$ pathway responsible for heart formation may act (directly or indirectly) via dTCF-independent binding sites and may employ transcription factor(s) other than dTCF. Moreover, expression of tinman in response to $w g$ may require additional, as yet unidentified transcription factors, which may influence tinman expression via their own elements in order to achieve cardiac specificity.

Although $d p p$ is required for maintaining tinman expression within the dorsal mesoderm, which in turn is essential for both cardiac and visceral mesoderm formation (Staehling-Hampton et al., 1994; Frasch, 1995), it

FIG 1. Tinman protein and regulation of tinman expression. (A) Map of fragments from the of the tinman gene that regulate four discrete patterns of expression. B: BamHI, H: HindllI, R: EcoRI, N: Nhel, C: Cla I, X: Xho I, EM: early mesoderm, DM: dorsal mesoderm, VM: visceral mesoderm, PC: pericardial heart cells, CC: myocardial heart cells. Black bars indicate exons. (B-E) Tinman protein. (B) Stage 9 embryo showing Tinman localization in all trunk mesoderm nuclei (arrowheads). (C) Stage 10 embryo showing restriction of Tinman to the dorsal mesoderm (arrowheads). (D) Stage 11/12 embryo showing Tinman in the cardiac (arrowheads) and visceral (arrows) mesoderm. (E) Stage 15/16 embryo showing Tinman in myocardial (arrowheads) and pericardial (arrows) cells of the newly assembled heart tube. Note that only four out of six cells per hemisegment are positive. (F-l) lacZ reporter gene expression visualized with anti-??gal antibodies. Due to the perdurance of $\beta$-gal, anti- $\beta$-gal staining is observed beyond the presence of endogenous Tinman protein. (F) Construct $2 \mathrm{~A}$ driving lac $Z$ reporter gene expression in the early mesoderm (arrowheads, stage 10 embryo). (G) Construct 103E driving lac $Z$ in the dorsal mesoderm (arrowheads, stage 11 embryo). (H) Construct 34 driving lac $Z$ in pericardial cells (arrowheads) and visceral mesoderm (not shown in this focal plane, stage 15/16 embryo). (I) Construct 73 driving lac $Z$ in the myocardial cells of heart (arrowheads, stage 15/16 embryo). Note the pattern of expression is similar to the myocardial expression of Tinman (E). seems that $d p p$ is needed again later, along with $w g$, to specify cardiac mesoderm at locations of persistent $w g$ / $d p p$ overlap. In support of this hypothesis, overexpression of $d p p$ generates cardiac-specific marker gene expression at the $w g / d p p$ intersects of the ventrolateral mesodermal cells (W.K. Lockwood and R. Bodmer, unpublished data). Thus, it is possible that normally the $d p p$ pathway directly regulates this heart enhancer, in addition to the dorsal mesoderm enhancer (Xu et al., 1998). The myocardial heart enhancer apparently does not contain consensus DNA binding sites for Smad proteins, as does the dorsal mesoderm enhancer (Xu et al., 1998), but rather depends on two CRE consensus sites. Mutating these CRE sites abolishes reporter gene expression conferred by this heart enhancer (Fig. 5). We do not know if or how the CRE sites of this enhancer are regulated by the $d p p$ pathway and/or by CREB proteins. In the case of the midgut enhancer of $U b x$, it had been shown that CRE sites act as $d p p$ response elements (Riese et al., 1997; Eresh et al., 1997). Moreover, overexpression of a dominant-negative form of the dCREB-B transcription factor suppresses the $d p p$ response of this midgut enhancer, suggesting $d p p$ signaling may normally modify dCREB activity or that of its partner (Eresh et al., 1997). In contrast, a CREB binding protein (dCBP) also binds dTCF in vitro (a $w g$-dependent transcription factor) and $\mathrm{dCBP}$ mutants interacts genetically with the $w g$ pathway in the midgut enhancer assay (Waltzer and Bienz, 1998). Therefore, it is possible that CREB proteins interact with the $d p p$ or the $w g$ pathway (or both) in regulating a heart enhancer of tinman. It will be interesting to see if mutant version of a dCREB and/or a dCBP affect myocardial tinman expression and/or heart formation.

Six vertebrate homologs of tinman have been identified thus far (Bodmer, 1995; Harvey, 1996; Bodmer and Venkatesh, 1998), some of which exhibit an expression pattern that is remarkably similar to the cardiac restricted expression pattern of tinman. Of these, Nkx2-5 has been most extensively studied from Amphioxus to humans (Komuro and Izumo, 1993; Lints et al., 1993; Lyons et al., 1995; Lee et al., 1996; Schott et al., 1998; Tanaka et al., 1999; T.V.Venkatesh and R. Bodmer, unpublished data). Nkx2-5 is the first of the tinman homologs to be expressed in the bilaterally symmetrical cardiogenic regions of the anterior lateral plate mesoderm. The regulation of both tinman and Nkx2-5 appears to be encoded in a modular fashion in that spatially separate enhancers direct expression to different parts of the heart and its precursors (Yin et al., 1997; Xu et al., 1998; Searcy et al., 1998; Lien et al., 1999; Reecy et al., 1999; Tanaka et al., 1999; this study). The genomic distribution of the enhancers, however, seems to be different between tinman and Nkx2-5: tinman expression primarily depends on enhancer elements that are located either within or $3^{\prime}$ to the coding region, whereas the regulatory elements of $N k \times 2-5$ that have been identified so far appear to be located in the $5^{\prime}$ region, except 


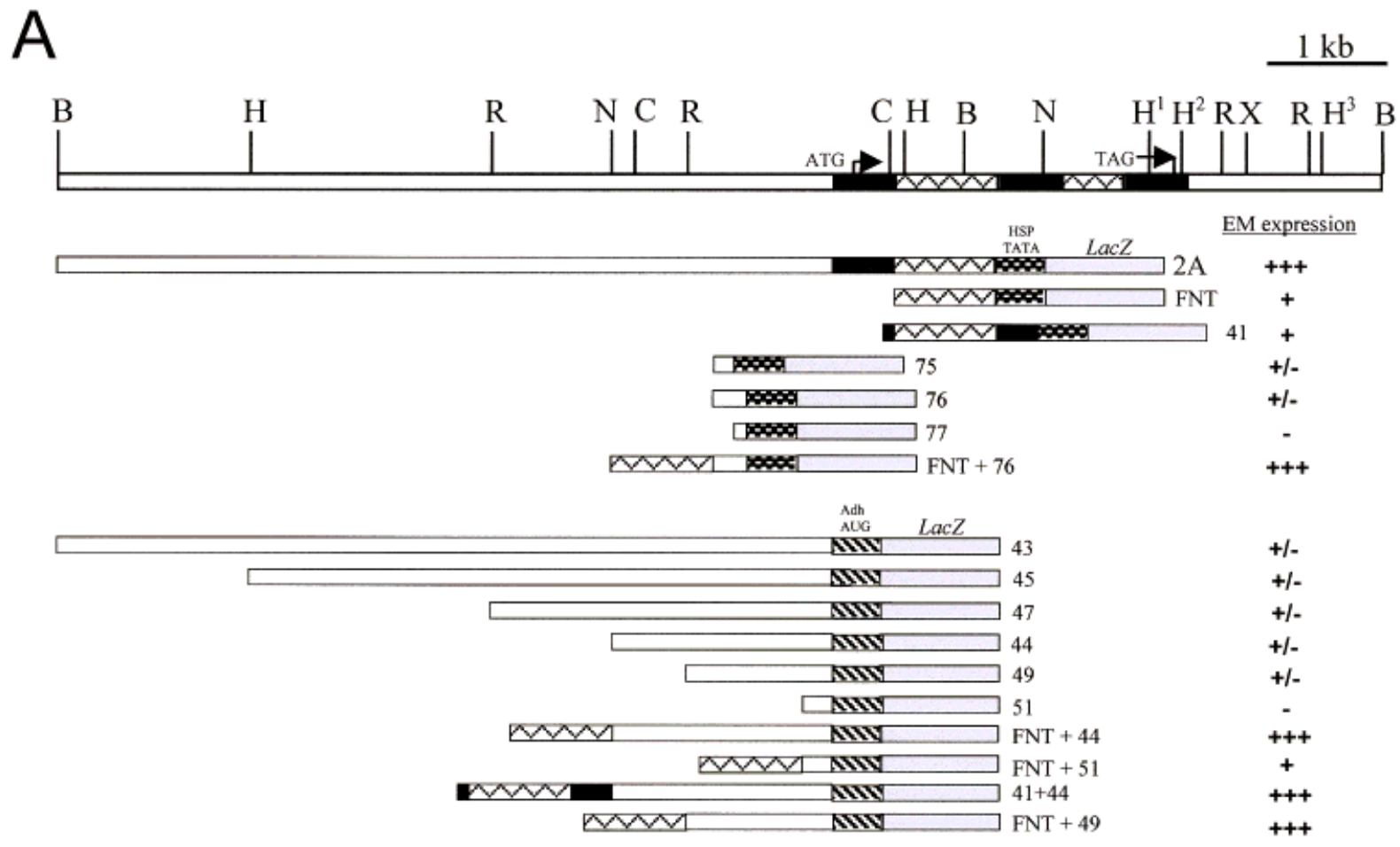

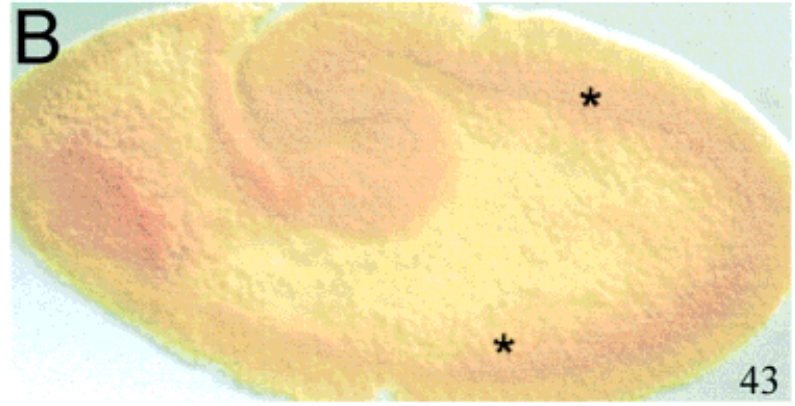

C

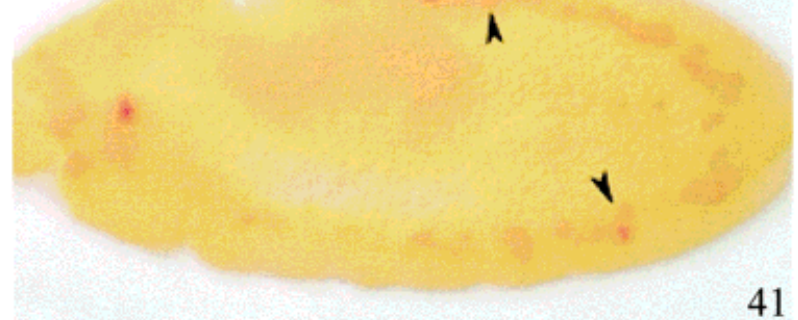

FIG 2. Localization of the early mesoderm tinman enhancer to the first intron (Yin et al., 1997) and $-1 \mathrm{~kb}$ region. (A) Map and expression summary of constructs used. (B) Construct 43 driving lac $Z$ (stage 11 embryo). Note absence of expression in the mesoderm

for one element in the $3^{\prime}$ region that causes expression in the right ventricle of the heart (Tanaka et al., 1999).

Interestingly, both tinman and $N k \times 2-5$ expression in the precardiac mesoderm are strongly responsive to

41
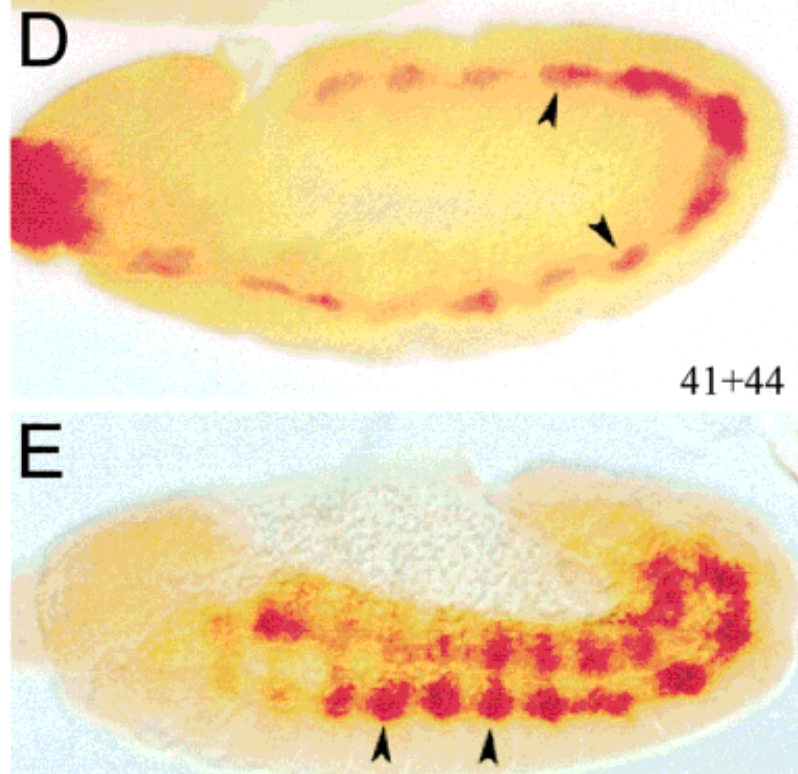

$76+\mathrm{FNT}$

(asterisks). (C) Intron I containing construct 41 driving lacZ in the mesoderm (arrowheads, stage 11 embryo). Construct $41+44$ driving lac $Z$ in the mesoderm (arrowheads, stage 11 embryo). Construct 76 + FNT driving lacZ (arrowheads, stage 12/13 embryo).

Dpp-like TGF- $\beta$ signals, which originate from adjacent germ layers (ectoderm and endoderm, respectively; Staehling-Hampton et al., 1994; Frasch, 1995; Schultheiss et al., 1995; 1997; see also review by Nascone and 
A
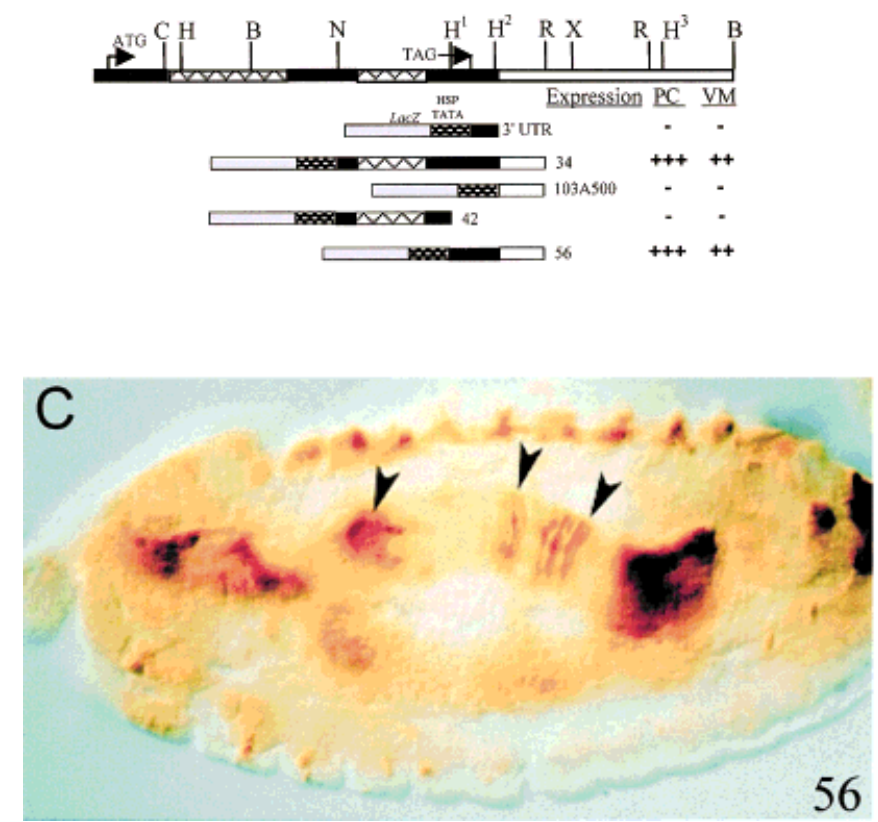

FIG 3. Analysis of the pericardial/visceral mesoderm tinman enhancer. (A) Map and expression summary of constructs used. (B) Construct 56 driving lac $Z$ double labeled with anti-PC antibodies (dorsal view of stage 15 embryo). Note the coincidence of lacZ

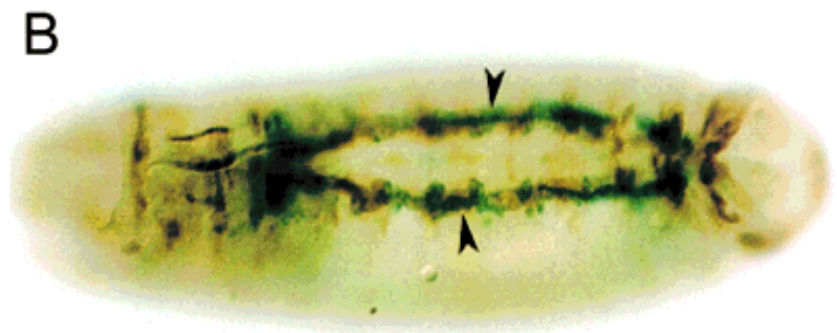

56

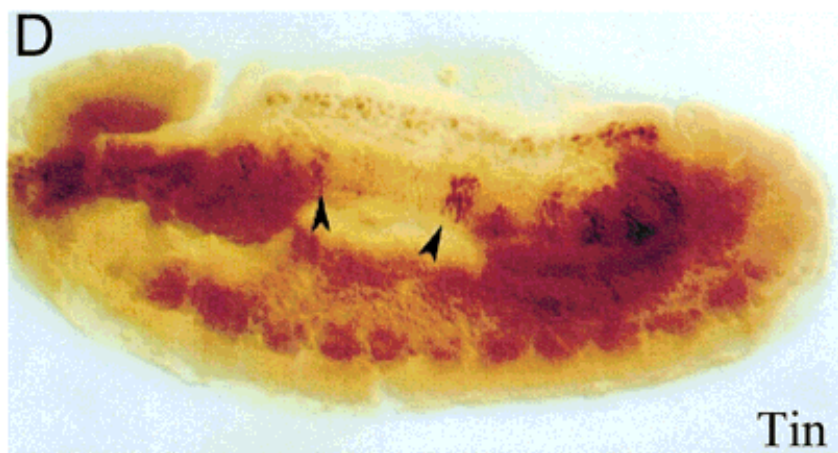

expression with pericardial cells (arrowheads). (C) Construct 56 driving lac $Z$ in a subset of the visceral mesoderm (arrowheads, lateral view of stage 13 embryo). (D) Same stage embryos as (C) showing Tinman expression in visceral mesoderm (arrowheads).
Mercola, 1995). Since in Drosopbila dorsal mesodermal and cardiac tinman expression appears to be mediated by Smad and CREB sites, respectively, it will be interesting to see if $N k x 2-5$ expression also depends on Smad and/or CREB consensus sites.

\section{MATERIALS AND METHODS}

\section{Tinman Antibody Production}

In order to generate Tinman protein products in vitro, DNA fragments to be inserted into expression vectors were prepared by PCR using the full-length tinman cDNA as a template. One DNA fragment contained the full length tinman protein coding region minus the stop codon (1245 bp, forward primer: 5' - CCC GCG GAT CCA TGT TGC AGC ACC ATC AGC AGC AGG-3', reverse primer 5'-CGA CCC GGG CAT GTG CTG CAT CTG TTG CTG CTG- $3^{\prime}$ ). The other fragment contained a smaller portion of the tinman coding region that included the homeodomain-containing $3^{\prime}$ end of the gene, also without the stop codon (508 bp, forward primer: 5'-CGC GGA TCC GCG ATG AAG CGA AAG CCT-3', reverse primer same a for full-length). These constructs were subcloned into the BamHI and XmaI sites of the pQE30 vector (Qiagen; Chatsworth, CA), which contains an inducible promoter and a $3^{\prime}$ sequence coding for six histidine residues $(6 \times$ His tag) followed by a stop codon. Proteins produced by this expression construct contain this $6 \times$ His tag which permits their rapid purification using Ni-NTA chromatography (see below). Both tinman inserts were engineered with a 5' BamHI site and a 3' XmaI site for unidirectional cloning. Polymerase chain reaction (PCR) fragments and the pQE30 vector were digested with these two restriction enzymes followed by ligation and transformation into competent JM107 cells. Transformants were identified by their ability to produce an appropriately sized protein in response to induction by isopropyl- $\beta$-D-thiogalactopyranoside (IPTG, see below).

Transformants were cultured overnight at $37^{\circ} \mathrm{C}$ in the presence of ampicillin and kanamycin. Cells were then induced with $1 \mathrm{mM}$ IPTG and cultured for an additional $4 \mathrm{~h}$ at $37^{\circ} \mathrm{C}$. After centrifugation the pelleted cells were solubilized in guanidine buffer ( $6 \mathrm{M}$ guanidine $\mathrm{HCl}, 0.1$ $\mathrm{M} \mathrm{NaH} \mathrm{PO}_{4}, 0.01 \mathrm{M}$ Tris $\left.\mathrm{HCl}, \mathrm{pH} 8\right)$. Solubilized fusion proteins were placed on columns containing Ni-NTA resin that binds the $6 \times$ His affinity tag. Columns were washed with 20 volumes guanidine buffer, 20 volumes buffer B (8 M urea, 0.1 $\mathrm{M} \mathrm{NaH}_{2} \mathrm{PO}_{4}, 0.01 \mathrm{M}$ Tris $\mathrm{HCl}, \mathrm{pH}$ $8)$ and the 20 volumes buffer $C(8 \mathrm{M}$ urea, $0.1 \mathrm{M}$ $\mathrm{NaH}_{2} \mathrm{PO}_{4}, 0.01 \mathrm{M}$ Tris $\mathrm{HCl}, \mathrm{pH}$ 6.3). The bound fusion protein was eluted with an imidazole/urea buffer (250 $\mathrm{mM}$ imidazole, $8 \mathrm{M}$ urea, $0.1 \mathrm{M} \mathrm{NaH}_{2} \mathrm{PO}_{4}, 0.01 \mathrm{M}$ Tris $\mathrm{HCl}, \mathrm{pH}$ 7.5. Eluted fusion protein was dialyzed using a step-wise dilution of urea $(6 \mathrm{M}, 4 \mathrm{M}, 2 \mathrm{M}, 0 \mathrm{M}$ urea, in 0.5 $\mathrm{M} \mathrm{NaCl}, 0.01 \%$ Tween, $0.1 \%$ NP40 and $1 \mathrm{mM}$ DTT). The 
A

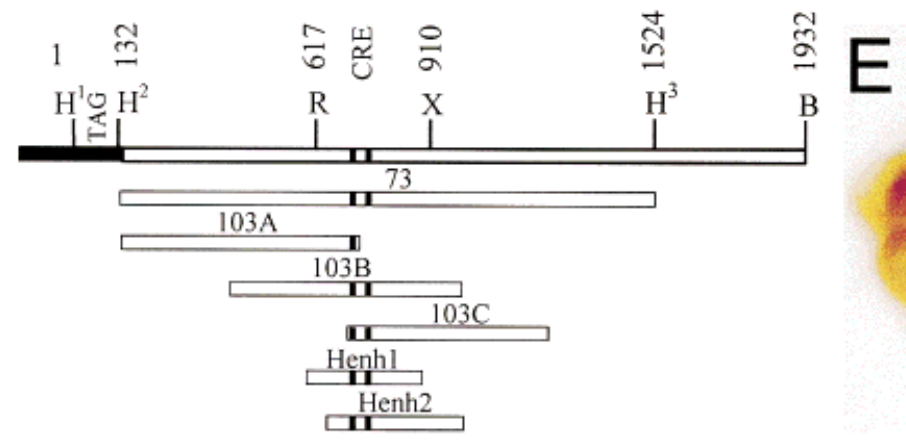

\section{2xHenh1}
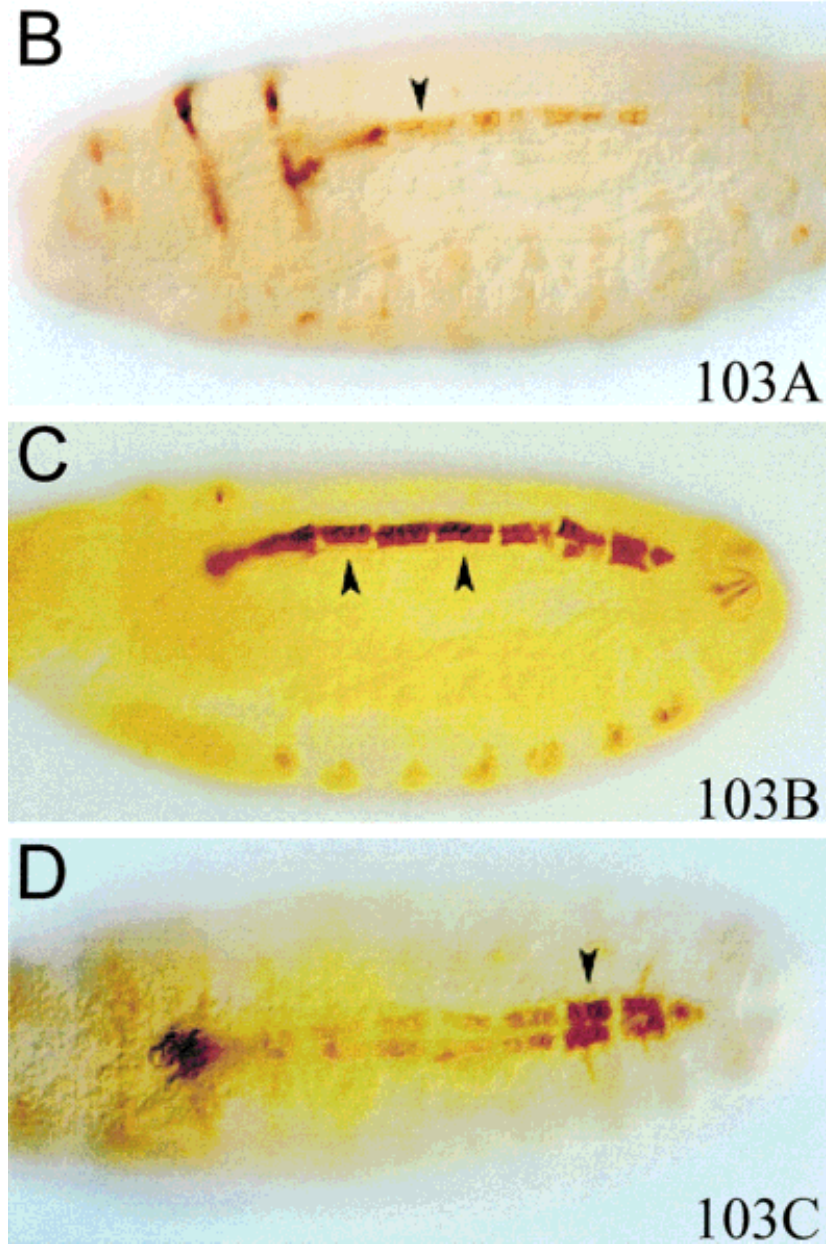

FIG 4. Analysis of the myocardial tinman enhancer. (A) Map and expression summary of constructs used. (B-F) Dorsal view of stage $15 / 16$ embryos. (B) Construct $103 \mathrm{~A}$ driving lac Z preferentially in the anterior myocardial cells (arrowhead). (C) Construct 103B driving lac $Z$ strongly in myocardial cells along the entire heart and in the identical pattern as construct 73 (Fig. 1I). (D) Construct 103C driving lacZ preferentially in the posterior myocardial cells (arrowhead). (E-H) Two copies of Henh1 construct driving lacZ. (E) lacZ expression in all myocardial (arrowheads) and more weakly in all pericardial

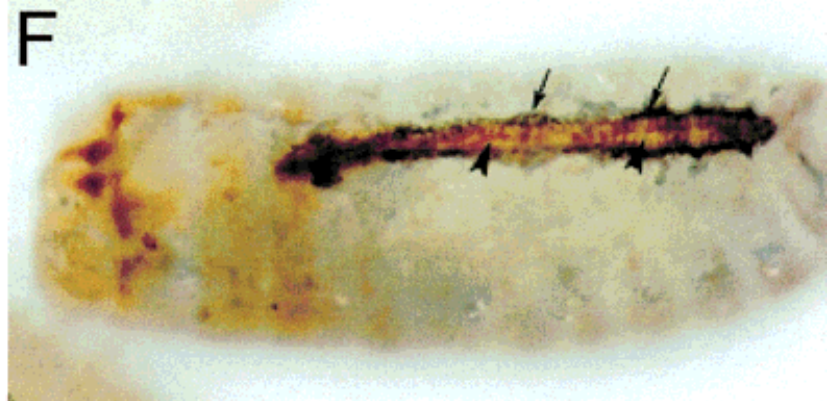

\section{G}
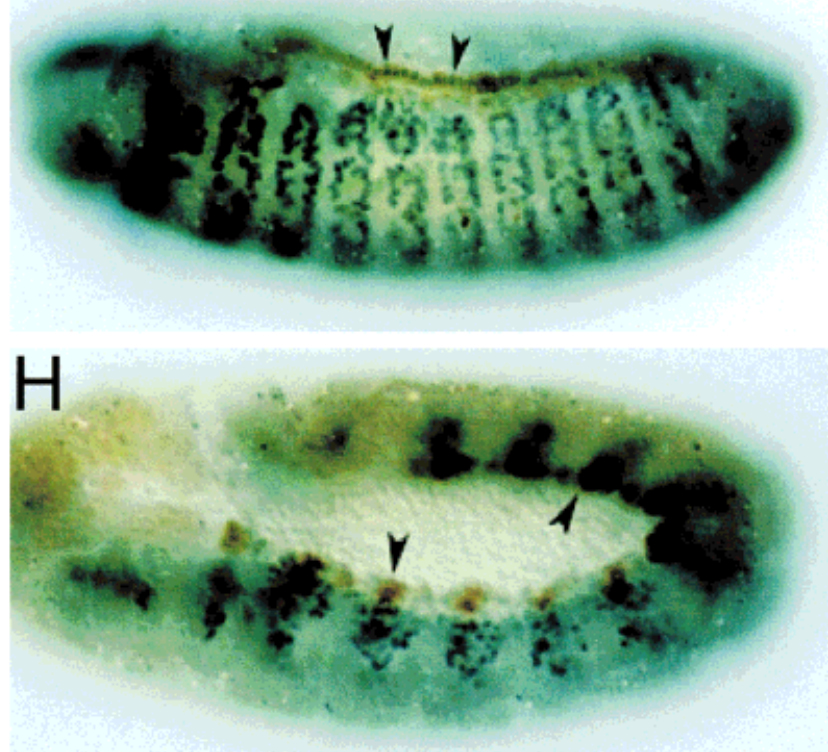

cells (arrows) of the heart. Note that the myocardial cells that normally do not express tinman express lacZ more weakly. (F) Embryo double-labeled with anti-PC (blue) and anti- $\beta$-gal showing the juxtaposition anti-PC labeled pericardial cells next to strongly lac $Z$ expressing myocardial cells. (G) Note the coincidence of lacZ (brown) and Dmef2 expression (blue) in the myocardial cells (arrowheads, stage 14 embryo). (H) Note the coincidence of lac $Z$ and Dmef2 expression in the forming cardiac mesoderm (arrowheads, stage 11 embryo). 
A

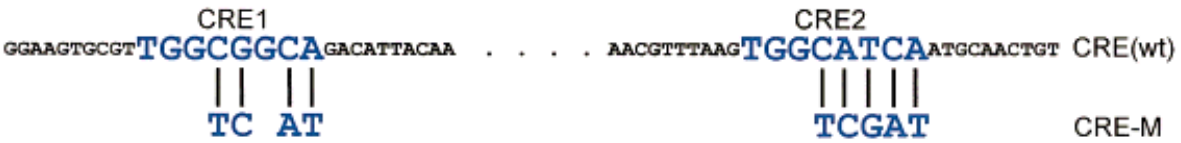

FIG 5. Mutated CREB consensus binding sites abolishes cardiac expression of myocardial heart enhancer. (A) Wild-type and mutant sequence of CRE1/2-containing Henh1. (B) Stage 11/12 embryo containing one copy of wild-type Henh1 driving lacZ. Note expression in the cardiac mesoderm (arrowheads). All five independent insertions of Henh1 $(1 \times$ and $2 \times)$ showed strong expression in the cardiac mesoderm. (C) Stage 11/12 embryo containing one copy of CRE1/2-mutated Henh1 driving lacZ. Note the lack lacZ expression in the cardiac mesoderm (asterisks). All four independent insertions of the mutated Henh1 construct lacked expression in the cardiac mesoderm.

final solution, which lacked urea, included $20 \mathrm{mM}$ phosphate-buffered saline (PBS) (pH 7.5) and 20\% glycerol. Most of the fusion protein remained soluble under these conditions. Sodium dodecyl sulfate (SDS) gel electrophoresis of the solution showed that the majority of the solubilized protein in all samples migrated as single band (data not shown). There were a few additional bands containing relatively insignificant amounts of protein. (These were later determined to be degradative products of the Tinman fusion proteins.) Consequently, the proteins used for antibody production were obtained by preparative SDS gel electrophoresis of the solutions containing the eluted fusion proteins. Regions of polyacrylamide gels that contained the primary fusion protein band were excised and frozen.

Anti-Tinman antibodies were prepared by ImmunoDynamics Inc. (La Jolla, CA.). A combination of both the full-length Tinman fusion protein as well as the smaller homeodomain-containing protein were used as antigens in each of two rabbit. Excised gel bands containing Tinman fusion proteins were injected into rabbits following standard procedures. Animal were boosted four times and the sera obtained following the final boost was purified with CM Affi-Gel blue (Bio-Rad; Richmond, CA) affinity chromatography to produce the protease free globulin fraction used in these studies.

\section{Generation of Promoter-lacZ Constructs and Transgenic Flies}

Cloning of genomic region of tinman is described in Bodmer (1993) and Azpiazu and Frasch (1993). Position -1 of the genomic DNA sequence is defined as the base before the first ATG codon of the open reading frame of the tinman cDNA (Bodmer et al., 1990). Position +1 is 
defined as first base after the TAG stop codon of the tinman cDNA. Intron sequences are numbered separately.

Construct 2A was made with the $8.0 \mathrm{~kb}$ BamHI upstream fragment that extends into intron I (see Fig. 1A). $2 \mathrm{~A}$ was blunted and subcloned into the StuI cloning site of the vector pWHL, which contains the hsp70-TATAbox (providing a core promoter) in front of the lacZ coding region (Ip et al., 1992). Three restriction fragments, $1.4 \mathrm{~kb}$ ClaI-NheI (intron I containing construct 41), $0.7 \mathrm{~kb}$ NheI-HindIII ${ }^{1}$ (intron II containing construct 42) and $1.64 \mathrm{~kb}$ NheI-EcoRI (construct 34, containing intron II and $3^{\prime}$ coding and noncoding sequences), were subcloned the same way into pWHL. A $1.0 \mathrm{~kb}$ HindIII ${ }^{1}$ EcoRI fragment (construct 56) having part of the third exon, the $3^{\prime}$ UTR and some $3^{\prime}$ noncoding region was generated by partially digesting the NheI-EcoRI fragment with HindIII before subcloning into pWHL. Intron I (807 bp) was also amplified by PCR using plaque-forming units (pfu) polymerase and primers pairs which had an overhang of sequences for SphI site. The forward primer was 5'-CCG GCA TGC GTA AGC TTG GAA GTT TTG AA- 3 ' and the reverse primer was 5'-GGC GCA TGC GCA TGC GCG CTG CGG GAA AGC AG-3'. The PCR product was digested with SphI and cloned into pWHL. The identity of the constructs was confirmed by sequencing. Short regions of $5^{\prime}$ upstream region were cloned in a similar way. Construct 75 ( -1159 to $-959,202 \mathrm{bp})$ was amplified with forward primer 5'-GCC GCA TGC TAT GTA TAT GTG TGT ACT GT-3' and reverse primer 5'GGC GCA TGC CAC TTG AAA CTG TTA TGA TT-3'. Construct $76(-1159$ to $-807,352 \mathrm{bp})$ was amplified using forward primer 5'-GCC GCA TGC TAT GTA TAT GTG TGT ACT GT-3' and reverse primer 5'-CGG GCA TGC GCG TCT TGT GTA TTA AAC GG-3'. Construct 77 $(-928$ to $-801,120 \mathrm{bp})$ was amplified by forward primer 5'-GCC GCA TGC TTT AAA CCA AAC ATA TTC CC-3' and reverse primer 5'-CGG GCA TGC GCG TCT TGT GTA TTA AAC GG-3'.

An upstream $2.1 \mathrm{~kb}$ genomic ClaI fragment that also contains part of exon I including position -1 was subcloned into pBSK + . From this subclone, sequences upstream of $-1 \mathrm{bp}$ (deleting the native ATG) was amplified using the $\mathrm{T} 7$ primer and an internal reverse primer (from -20 to -1 , primer sequence 5 '-TTC GGT ACC CCT CGC TGT GCG ATC ACT TG-3') with a restriction site overhang of KpnI. The PCR product was cut with KpnI and ClaI and subcloned into pBSK + (construct 35). The identity of the PCR product was confirmed by cycle sequencing. Construct 35 was then digested with KpnI and BamHI and subcloned into the KpnI-BamHI site of pCasper-AUG-ßgal (Thummel et al., 1988) (construct 44). $5^{\prime}$ deletions of construct 35 were made by digesting with EcoRI and KpnI (construct 49, -1085 to -1 ) or PvuII and KpnI (construct $51,-372$ to -1 ) and ligating into pCasper-AUG- $\beta$ gal similar to construct 44 . Larger fragments that included region upstream of the ClaI site were generated by fusing the different length genomic fragments into the ClaI site. Constructs 43,45 , and 47 were generated by fusing the BamHI-ClaI, HindIII-ClaI, and EcoRI-ClaI fragments, respectively, with construct 35 at the ClaI site. All deletions were subcloned into pCasper-AUG-ßgal as KpnI-BamHI or KpnI-EcoRI fragments.

To check the interaction of intron I and $5^{\prime}$ upstream region, intron I containing construct 41) was subcloned into ClaI site of construct 35 to fuse with upstream region (construct $41+44)$. To further test the results from construct $41+44$, intron I sequences from construct FNT were also fused with construct 51 and 44 at the PvuII and ClaI sites, respectively, to generate constructs FNT +51 and FNT +44 , respectively. Fusions of construct 76 and the first intron sequences were also generated. This was achieved by PCR amplification of region 76 using same forward primer (described above) but with an overhang of sequences for XbaI and same reverse primer sequence (described above) with an overhang of sequences for SphI site. Similarly I intron sequences were generated by PCR using forward and reverse primer with an overhang of SphI and XbaI sites. Both PCR products were purified, digested with SphI and $\mathrm{XbaI}$, mixed and ligated into SphI site of pWHL, to generate FNT +76 . Orientation and the sequence in the final insert were verified by sequencing.

A $1.4 \mathrm{~kb}$ HindIII $(+132$ to +1524$)$ fragment $\left(\mathrm{H}^{2} \mathrm{H}^{3}\right.$ see Fig.1A) of the $3^{\prime}$ region was subcloned into StuI site of pWHL after blunting the ends (construct 73). Primers (listed below) were made with SphI overhangs and fragments were amplified using pfu polymerase. SphI digested PCR fragments were subcloned into SphI site of the pWHL vector. Fragment 103A ( +132 to $+744,612$ bp) was amplified with 5'-GCC GCA TGC AAG CTT AAG ACC AAT CAG TT-3' (forward) and 5'-GGC GCA TGC CCA ACG CAC TTC CCC TTT CC-3' (reverse), fragment $103 \mathrm{~A} 500(+132$ to $+633,501 \mathrm{bp})$ with $5^{\prime}$-GCC GCA TGC AAG CTT AAG ACC AAT CAG TT-3' (forward) and 5'- GGC GCA TGC GAA TTC GTT TTT CAT AAA AC-3' (reverse), fragment 103B $(+402$ to $+1022,611 \mathrm{bp})$ with 5'-GCC GCA TGC TCA GCT AAA GAT CAA TCA GA-3' (forward) and 5'-GGC GCA TGC CTG CAA CCC CCC GTT TAC CC-3' (reverse), fragment 103C (+722 to $+1232,530 \mathrm{bp}$ ) with 5'-GCC GCA TGC AGT GCG TTG GCG GCA GAC AT-3' (forward) and 5'-GGC GCA TGC TCC AGT AAC TAT TTG ATG TC-3' ' (reverse), fragment 103D (+1232 to +1832, $650 \mathrm{bp})$ with 5'-GCC GCA TGC CGG GTA AAC GGG GGG TTG CA-3' (forward) and 5'-GGC GCA TGC TAT AAA ATG TCT TGG CTA AA-3' (reverse), fragment 103E $(+1332$ to $+1932,701 \mathrm{bp})$ with 5'-CGG GCA TGC GAG ACA TCA AAT AGT TAC TG-3' (forward) and 5'-GGC GCA TGC GGA TCC TCG ACG GAG GGG CA-3' (reverse), Henh1 (+616bp to +921bp, 305 bp) with 5'-GCC GCA TGC GAA TTC GAA GGC GAA CGG CA-3' (forward) and 5'-GGC GCA TGC CTC GAG CCC CCA ATG AAA TA-3' (reverse), and Henh2 (+661 to $+913,362$ bp) with 5'-GCC GCA TGC AAT TGA AAT GTT TTC CCT TT-3' (forward) and 5'GGC GCA TGC GCT GCA ACC CCC CGT TTA CC-3' (reverse). Two copies of Henh1 $(2 \times)$ were made using 
the same forward and reverse primers: in one reaction forward primers with SphI overhang and reverse primer with XbaI overhang were used, in the other reaction forward primers with XbaI overhang and reverse primers with SphI overhang were used. PCR products from both reactions were purified from gel, digested with $\mathrm{XbaI}$ and SphI, and ligated into SphI site of pWHL (in head to tail orientation). Mutations in CRE sites of Henh1 were created in two PCR steps using overlapping mutant oligos and the forward and reverse primers described above for Henh1. Sequence of the mutant CRE1 oligo was 5'-AGG TTG CAT TTA TGA AAC GTT TAA GTG GTC GAT ATG C- $3^{\prime}$ and sequence of the mutant CRE2 oligo was 5 ' - TCA TAA ATG CAA CCT TTG TAA TGT CAT CGA CCA ACG CAC T-3' (see Fig. 5A). The first two PCR products were generated using mutant CRE1 oligo and reverse Henh1 primer in one PCR reaction and mutant CRE2 oligo and forward Henh1 primer in another reaction. Both PCR products were separated on an agarose gel, purified, mixed together, denatured and reannealed. From this mixture, DNA carrying mutations in both CREB sites was amplified by the Henh1 forward and reverse primers. The final PCR product was purified, sequenced and then subcloned into the SphI site of pWHL.

Transgenic flies were generated by injecting early blastoderm embryos of the genotype $w ;+/+;+/+$ with the tinman enhancer-lac $Z$ reporter constructs $(100 \mu \mathrm{g} /$ $\mathrm{ml})$ along with transposase-containing helper plasmid $(50 \mu \mathrm{g} / \mathrm{ml})$ according to standard procedures (Spradling, 1986; Pirrotta, 1988). Three to six independent transformants were analyzed for each promoter or enhancer construct.

\section{Immunocytochemistry}

Immunohistochemical staining of fixed embryos was performed as described (Bodmer, 1993; Su et al., 1998). Antibodies and dilutions were as follows: anti-Dmef-2 antibodies were used at 1:1,000 (Lilly et al., 1995), antibodies against a pericardial-specific cell surface antigen were used at 1:10 (Wu et al., 1995; Yarnitzky and Volk, $1995)$, and affinity-purified mouse or rabbit anti- $\beta$-galactosidase antibodies (anti- $\beta$-gal) were used at 1:1,000 and 1:4,000, respectively (Cappell; Malverne, PA). For double antibody staining the protocol by (Su et al., 1998) was followed, except that during the color reaction the substrate for horseradish peroxidase, diaminobenzidine (Sigma; St. Louis, MO), was used first (brown staining), followed by the Chromogen (SG substrate kit, Vector Laboratories; Burlingame, CA) color reaction (blue-gray staining). For some antibody staining, the ABC Elite kit (Vector Laboratories) was used to enhance the signal according to the manufacturer's instructions.

\section{ACKNOWLEDGMENTS}

We would like to thank B. Patterson, T. Volk for antibodies, M. Liu and W.K. Lockwood for comments and J. Guzman for help preparing the manuscript. T.V.V. was in part supported by the Michigan chapter of the American Heart Association. This work was supported by a grant from National Institutes of Health to R.B.

\section{LITERATURE CITED}

Abmayr, SM, Erickson MS, Bour BA. 1995. Embryonic development of the larval body wall musculature of Drosophila melanogaster. Trends Genet 11:153-159.

Azpiazu, N Frasch M. 1993. Tinman and bagpipe: Two homeobox genes that determine cell fates in the dorsal mesoderm of Drosopbila. Genes Dev 7:1325-1340.

Azpiazu N, Lawrence PA, Vincent J-P, Frasch M. 1996. Segmentation and specification of the Drosophila mesoderm. Genes Dev 10: 3183-3194.

Baylies MK, Bate M, Ruiz GM. 1998. Myogenesis: A view from Drosopbila. Cell 93:921-927.

Baylies, MK, Martinez-Arias A, Bate M. 1995. Wingless is required for the formation of a subset of muscle founder cells during Drosophila embryogenesis. Development 121:3829-3837.

Beiman M, Shilo BZ, Volk T. 1996. Heartless, a Drosopbila FGF receptor homolog, is essential for cell migration and establishment of several mesodermal lineages. Genes Dev 10:2993-3002.

Bodmer R. 1993. The gene tinman is required for specification of the heart and visceral muscles in Drosophila. Development 118:719729.

Bodmer R. 1995. Heart development in Drosopbila and its relationship to vertebrate systems. Trends Cardiovasc Med 5:21-28.

Bodmer R, Jan LY, Jan YN. 1990. A new homeobox-containing gene, $m s h-2$, is transiently expressed early during mesoderm formation of Drosophila. Development 110:661-669.

Bodmer R, Venkatesh TV. 1998. Heart development in Drosophila and vertebrates: Conservation of molecular mechanisms. Dev Genet 22:181-186.

Bodmer R, Frasch M. 1999. Genetic determination of Drosopbila heart development. In: Rosenthal N, Harvey R, editors. Heart development. San Diego: Academic Press. p 65-90.

Bour BA, O'Brien MA, Lockwood WL, Goldstein ES, Bodmer R, Taghert PH, Abmayr SM, Nguyen HT. 1995. Drosopbila MEF2, a transcription factor that is essential for myogenesis. Genes Dev 9:730 -741.

Broihier HT, Moore LA, Van Doren M, Newman S, Lehmann R. 1998. $z f b-1$ is required for germ cell migration and gonadal mesoderm development in Drosophila. Development 125:655-666.

Cripps RM, Black BL, Zhao B, Lien CL, Schulz RA, Olson EN. 1998. The myogenic regulatory gene $M e f 2$ is a direct target for transcriptional activation by Twist during Drosophila myogenesis. Genes Dev 12:422- 434

Eresh S, Riese J, Jackson DB, Bohmann D, Bienz M. 1997. A CREBbinding site as a target for decapentaplegic signalling during Drosopbila endoderm induction. EMBO J 16:2014-2022.

Frasch M. 1995. Induction of visceral and cardiac mesoderm by ectodermal Dpp in the early Drosopbila embryo. Nature (London) 374:464-467.

Fujioka M, Emi-Sarker Y, Yusibova GL, Goto T, Jaynes JB. 1999. Analysis of an evenskipped rescue transgene reveals both composite and discrete neuronal and early blastoderm enhancers, and multistripe positioning by gap gene repressor gradients. Development 126:2527-2538

Gisselbrecht S, Skeath JB, Doe CQ, Michelson AM. 1996. beartless encodes a fibroblast growth factor receptor (DFR1/DFGF-R2) involved in the directional migration of early mesodermal cells in the Drosopbila embryo. Genes Dev 10:3003-3017.

Harvey RP. 1996. NK-2 homeobox genes and heart development. Dev Biol 178:203-216.

Ip YT, Park RE, Kosman D, Yazdanbakhsh K, Levine M. 1992. Dorsaltwist interactions establish snail expression in the presumptive mesoderm of the Drosopbila embryo. Genes Dev 6:1518-1530.

Komuro I, Izumo S 1993. Csx: a murine homeobox-containing gene specifically expressed in the developing heart. Proc Natl Acad Sci USA 90:8145-8149. 
Lai Z, Fortini ME, Rubin GM. 1991. The embryonic expression patterns of $z f h-1$ and $z f b-2$, two Drosophila genes encoding novel zincfinger homeodomain proteins. Mech Dev 34:123-134.

Lai Z, Rushton E, Bate M, Rubin GM. 1993. Loss of function of the Drosophila zfh-1 gene results in abnormal development of mesodermally derived tissues. Proc Natl Acad Sci USA 90:4122- 4126.

Lawrence PA, Bodmer R, Vincent J-P. 1995. Segmental patterning of heart precursors in Drosophila. Development 121:4303-4308.

Lee KH, Xu Q, Breitbart RE. 1996. A new tinman-related gene, $n k x 2.7$, anticipates the expression of $n k \times 2.5$ and $n k \times 2.3$ in zebrafish heart and pharyngeal endoderm. Dev Biol 180:722-731.

Lee YM, Park T, Schulz RA, Kim Y. 1997. Twist-mediated activation of the NK- 4 homeobox gene in the visceral mesoderm of Drosophila requires two distinct clusters of E-box regulatory elements. J Biol Chem 272:17531-17541

Lien CL, Wu C, Mercer B, Webb R, Richardson JA, Olson EN. 1999. Control of early cardiac-specific transcription of Nkx2-5 by a GATA-dependent enhancer. Development 126:75-84.

Lilly B, Galewsky S, Firulli AB, Schulz RA, Olson EN. 1994. D-MEF2: A MADS box transcription expressed in differentiating mesoderm and muscle cell lineages during Drosophila embryogenesis. Proc Natl Acad Sci USA 91:5662-5666.

Lilly B, Zhao B, Ranganayakulu G, Paterson BM, Schulz RA, Olson EN. 1995. Requirement of MADS domain transcription factor D-MEF2 for muscle formation in Drosophila. Science 267:688-693.

Lints TJ, Parsons LM, Hartley L, Lyons I, Harvey RP. 1993. Nkx-2.5: A novel murine homeobox gene expressed in early heart progenitor cells and their myogenic descendants. Development 119:419431.

Lyons I, Parsons LM, Hartley L, Li R, Andrew JE, Robb L, Harvey RP. 1995. Myogenic and morphogenetic defects in the heart tubes of murine embryos lacking the homeobox gene $N k x 2-5$. Genes Dev 9:1654-1666

Nascone N, Mercola M. 1995. An inductive role for the endoderm in Xenopus cardiogenesis. Development 121:515-523.

Nguyen HT, Bodmer R, Abmayr S, McDermott JC, Spoerel NA, NadalGinard B. 1994. D-mef2: A new Drosophila mesoderm-specific MADS box-containing gene with a bi-modal expression profile during embryogenesis. Proc Natl Acad Sci USA 91:7520-7524.

Nguyen HT, Xu X. 1998. Drosophila mef2 expression during mesoderm development is controlled by a complex array of cis-acting regulatory modules. Dev Biol 204:550-566.

Park M, Wu X, Golden K, Axelrod JD, Bodmer R. 1996. The wingless signaling pathway is directly involved in Drosophila heart development. Dev Biol 177:104-116.

Pirrotta V. 1988. Vectors for P-mediated transformation in Drosophila. In A survey of molecular cloning vectors and their uses. Boston: Buttersworth.

Ranganayakulu G, Zhao B, Dokidis A, Molkentin JD, Olson EN, Schulz RA. 1995. A series of mutations in the D-MEF2 transcription factor reveal multiple functions in larval and adult myogenesis in Drosophila. Dev Biol 171:169-181.

Ranganayakulu G, Schulz RA, Olson EN. 1996. Wingless signaling induces nautilus expression in the ventral mesoderm of the Drosophila embryo. Dev Biol 176:143-148.

Reecy JM, Li X, Yamada M, DeMayo FJ, Newman CS, Harvey RP, Schwartz RJ. 1999. Identification of upstream regulatory regions in the heart-expressed homeobox gene Nkx2-5. Development 126:839-849.

Riechmann V, Irion U, Wilson R, Grosskortenhaus R, Leptin M. 1997. Control of cell fates and segmentation in the Drosophila mesoderm. Development 124:2915-2922.

Riese J, Yu X, Munnerlyn A, Eresh S, Hsu SC, Grosschedl R, Bienz M. 1997. LEF-1, a nuclear factor coordinating signaling inputs from wingless and decapentaplegic. Cell 88:777-787.
Schott JJ, Benson DW, Basson CT, Pease W, Silberbach GM, Moak JP, Maron BJ, Seidman CE, Seidman JG. 1998. Congenital heart disease caused by mutations in the transcription factor NKX2-5. Science 281:108-111.

Schultheiss TM, Xydas S, Lassar AB. 1995. Induction of avian cardiac myogenesis by anterior endoderm. Development 121:4203-4214.

Schultheiss TM, Burch JB, Lassar AB. 1997. A role for bone morphogenetic proteins in the induction of cardiac myogenesis. Genes Dev 11:451- 462 .

Searcy RD, Vincent EB, Liberatore CM, Yutzey KE. 1998. A GATAdependent nkx-2.5 regulatory element activates early cardiac gene expression in transgenic mice. Development 125:4461-4470.

Shishido E, Higashijima S-I, Emori Y, Saigo K. 1993. Two FGF-receptor homologues of Drosophila: One is expressed in mesodermal primordium in early embryos. Development 117:751-761.

Shishido E, Ono N, Kojima T, Saigo K. 1997. Requirements of DFR1/ Heartless, a mesoderm-specific Drosophila FGF- receptor, for the formation of heart, visceral and somatic muscles, and ensheathing of longitudinal axon tracts in CNS. Development 124:2119-2128.

Spradling, A. 1986. P-element mediated transformation. In: Roberts DB, editor. Drosophila: A practical approach. Oxford: IRL Press. p 175-197.

Staehling-Hampton K, Hoffmann FM, Baylies MK, Rushton E, Bate M. 1994. $d p p$ induces mesodermal gene expression in Drosophila. Nature (London) 372:783-786.

Su MT, Golden K, Bodmer R. 1998. X-gal staining of Drosophila embryos compatible with antibody staining or in situ hybridization. Biotechniques 24:918-922.

Su MT, Fujioka M, Goto T, Bodmer R. 1999. The Drosophila homeobox genes $z f h-1$ and evenskipped are required for cardiac-specific differentiation of a numb-dependent lineage decision. Development 126:3241-3251

Tanaka M, Chen Z, Bartunkova S, Yamasaki N, Izumo S. 1999. The cardiac homeobox gene $C s x / N k x 2.5$ lies genetically upstream of multiple genes essential for heart development. Development 126:1269-1280.

Thisse B, Stoetzel C, Gorositiza-Thisse C, Perrin-Schmitt F. 1988. Sequence of the twist gene and nuclear localization of its protein in endomesodermal cells of early Drosophila embryos. EMBO J 7:2175-2183.

Thummel CS, Bouolet AM, Libshitz HD. 1988. Vectors for Drosophila P-element-mediated transformation and tissue culture transfection. Gene 74:445-450.

van de Wetering M, Cavallo R, Dooijes D, van Beest M, van Es J, Loureiro J, Ypma A, Hursh D, Jones T, Bejsovec A, Peifer M, Mortin M, Clevers H. 1997. Armadillo coactivates transcription driven by the product of the Drosophila segment polarity gene dTCF. Cell 88:789-799.

Waltzer L, Bienz M. 1998. Drosophila CBP represses the transcription factor TCF to antagonize Wingless signalling. Nature (London) 395:521-525.

Wu X, Golden K, and Bodmer R. 1995. Heart development in Drosophila requires the segment polarity gene wingless. Dev Biol 169: $619-628$.

Xu X, Yin Z, Hudson JB, Ferguson EL, Frasch M. 1998. Smad proteins act in combination with synergistic and antagonistic regulators to target $d p p$ responses to the Drosophila mesoderm. Genes Dev 12:2354-2370.

Yarnitzky T, Volk T. 1995. Laminin is required for heart, somatic muscles, and gut development in the Drosophila embryo. Dev Biol 169:609-618.

Yin Z, Xu X-L, Frasch M. 1997. Regulation of the Twist target gene tinman by modular cis-regulatory elements during early mesoderm development. Development 124, 4971-4982. 